$10-2001$

\title{
Harold K. Jacobson (1929-2001): An Appreciation
}

Charlotte Ku

Texas A\&M University School of Law, cku@law.tamu.edu

Follow this and additional works at: https://scholarship.law.tamu.edu/facscholar

Part of the Law Commons

\section{Recommended Citation}

Charlotte Ku, Harold K. Jacobson (1929-2001): An Appreciation, 95 Am. J. Int'I L. 849 (2001).

Available at: https://scholarship.law.tamu.edu/facscholar/441

This Article is brought to you for free and open access by Texas A\&M Law Scholarship. It has been accepted for inclusion in Faculty Scholarship by an authorized administrator of Texas A\&M Law Scholarship. For more information, please contact aretteen@law.tamu.edu. 


\section{NOTES AND COMMENTS}

\section{HAROLD K. JACOBSON (1929-2001): AN APPRECIATION}

Harold Karan Jacobson died in Ann Arbor, Michigan, on August 13, 2001, at age 72, after a lifetime of teaching, scholarship, and service. He had just completed more than four decades of teaching, nearly all of it in the Department of Political Science at the University of Michigan, where he held the Jesse Siddal Reeves chair. "Call me Jake" was how so many conversations with him began. "Dad loved his work," was how one of his sons remembered him at his funeral.

Harold Jacobson was born in Detroit on June 28, 1929. He attended high school in Wyandotte, Michigan, and received a bachelor's degree in history from the University of Michigan. He married his Michigan schoolmate Merelyn Jean Lindbloom in 1951, a year after he started graduate school at Yale. Proud of his Norwegian heritage, he fulfilled a lifelong ambition in 1996, when he traveled to Norway's Sognefjord to see the Hovland farm from which his ancestors had emigrated to the United States.

Jacobson's manner was quiet and soft-spoken, but his reserve masked a deep passion. That passion was to wed intellectual discipline with broad and creative thinking in order to strengthen the ability of individuals to manage the challenges of contemporary life. He was fundamentally an optimist about human behavior; he opened his path-breaking text, Networks of Interdependence, with the words, "This is an optimistic book, though I hope not an unrealistic one." He was not naive about the complexity of the issues and was impatient with overgeneralizations and uncritical judgments.

His passion and his times converged as he began his academic career. In an autobiographical account, Jacobson wrote:

These [the 1950s and early 1960s] were the early days of the behavioral revolution. We saw ourselves as budding scientists. Following the ways of natural science, we would adhere to the tenets of logical positivism. There was much emphasis in our graduate training and early self-learning on gaining insights from the behavioral sciences, especially psychology, sociology, and anthropology. We were taught that our goal should be to search for generalizations about behavior in international relations. We thought that we could discover laws that governed international behavior. Although our positivist proclivities prohibited us from proclaiming it, we hoped that the generalizations would form the basis for prescriptions. ${ }^{2}$

As a budding scientist, Jacobson was not attracted to law or international law as an intellectual pathway to understanding and conditioning human behavior. Yet he admitted that, "[e]ven in the 1950s, I could not escape a nagging sense that to ignore international law was to ignore an important part of international relations," ${ }^{\text {.3 }}$ oting, for example, Arnold Wolfers's observation about states' pursuit of milieu goals. ${ }^{4}$

\footnotetext{
${ }^{1}$ HAROLD K. JACOBSON, NETWORKS OF INTERDEPENDENCE: INTERNATIONAL ORGANIZATIONS AND THE GLOBAL POLITICAL SYSTEM, at viii (2d ed. 1984).

${ }^{2}$ Harold K. Jacobson, Doing Collaborative Research on International Legal Topics: An Autobiographical Account, INT'L STUD. REv., Spring 2001, at 15, 15-16.

${ }^{3} I d$ at 16.

ARNOLd WOLFERS, DisCORd AND COLlaboration: Essays ON INTERNATIONAL POLITICS 3 (1962).
} 
Thus did Jacobson begin a career-long association with many whose work was rooted in international law. This interest led to fruitful collaborations and innovative contributions to the international law literature. His collaborators included several individuals prominently associated with the American Journal of Intermational Law-Eric Stein, ${ }^{5}$ Edith Brown Weiss, ${ }^{6}$ and Ruth Wedgwood. ${ }^{7}$ Jacobson further took pride in his membership on the $A J L$ Board of Editors. He was deeply aware of his special responsibility as a social scientist in this legal environment, and was admiring of the Journal s commitment to fostering a broad intellectual base on its board.

True to his calling, he applied his creativity, discipline, and ability to bringing together individuals representing different disciplines, nationalities, and ages to study some of the great issues of the twentieth century:

- Decolonization: The study of this subject took him to Africa eight times. Those journeys followed in the footsteps of Jesse Siddal Reeves, for whom the chair Jacobson held was named. Professor Reeves was not only the first chairman of the Department of Political Science at the University of Michigan, but also a vice president of the American Society of International Law and an early contributor to the AJLL on Africa.

- Environmental protection and climate change: His 1983 book, written with David Kay, focused on the international dimension of environmental protection. It was published under the auspices of the ASI research and studies program. ${ }^{8}$

- International institutions and democracy: In his last book, he led an international team of authors in exploring how trends toward democratization within states and basic constitutional understandings about the use of force fit with efforts to use military forces collectively. ${ }^{9}$

Equally important to him as interesting subjects was that the studies be broadly representative of "humankind." A gifted team builder, Jacobson was a pioneer and leader in many international collaborations. These efforts earned him numerous accolades, which he took pride in, but rarely trumpeted. These included the Award for International Scientific Cooperation of the American Association for the Advancement of Science in 1995, and his election as an AAAS Fellow in 1999-he was one of a small number of social scientists to achieve that distinction.Jacobson took his professional responsibilities seriously and contributed to the institutional lives of the associations to which he belonged. These included the American Society of International Law, which he served as a member of both the Executive Council and many committees.

His insatiable curiosity, open-mindedness, delight in discovery, and appreciation of people were grounded in a strong sense of his own community and identity. Jacobson, a son of the American Midwest, was too young to have served in World War II, but not too young to help shape the world to come through scholarship and teaching, and he was eager to do so. A lifetime at the University of Michigan gave expression to a strong commitment to public education. Although his network of students, friends, and collaborators was worldwide, Michigan was always home. Every fall he made sure that we had the latest news about Wolverine football.

An inspired and devoted teacher, Jacobson achieved excellence by fostering it. He rejoiced in the achievements of others. A considerate and generous colleague, he pursued

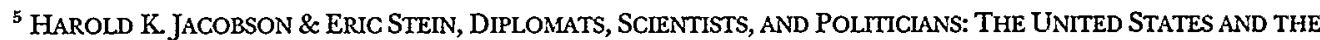
NUCLEAR TEST BAN NEGOTIATIONS (1966).

${ }^{6}$ ENGAGING COUNTRIES: STRENGTHENING COMPLIANCE WTTH INTERNATIONAL ENVIRONMENTAL ACCORDS (Edith Brown Weiss \& Harold K. Jacobson eds., 1998).

${ }^{7}$ Symposium, State Reconstruction After Civil Conflict, 95 AJIL 1 (2001). Jacobson edited this symposium with Wedgwood.

${ }^{8}$ DAVId KaY \& HAROLD K. JACOBSON, ENVIRONMENTAL PROTECTION: ThE INTERNATIONAL DimeNSION (1983).

${ }^{9}$ Charlotte Ku \& Harold K. Jacobson, Broaching the Issues, in DEMOCRATIC ACCOUNTABILITY AND THE USE OF FORCE IN INTERNATIONAL LAW (Charlotte Ku \& Harold K Jacobson eds., forthcoming 2002).
} 
excellence not only for its own sake, but for the sake of illumination, in the belief that in knowledge and understanding lies the path to a better world. He will be remembered as the nicest of persons, whose wisdom and gentleness touched all who were privileged to know and work with him.

I remember Jacobson for his quiet determination and uncanny ability to make complex situations easier to manage. As he embarked on what turned out to be his last journey in August (returning home from a workshop cosponsored by the ASIL and the Academic Council on the United Nations System), we stood for a moment in the glorious sunshine outside the departure terminal of Windhoek Airport in Namibia. He reflected on what an interesting place this new African country must be and what a pity it was that he did not have more time to explore it.

Many others will have personal remembrances of Harold Jacobson. We mourn his loss, but we are inspired by his life and work to foster collaboration, to continue exploration, and to pursue a passion for the discipline, honesty, and knowledge that contribute to the advancement of humankind. As we face the questions presented by the attacks of September 11, 2001, on New York and Washington, we will need his kind of gentle wisdom.

CHARLOTTE $\mathrm{Ku}^{*}$

\section{DEVELOPING HUMAN RIGHTS AND HUMANITARIAN LAW ACCOUNTABILITY OF THE SECURITY COUNCIL FOR THE IMPOSITION OF ECONOMIG SANCTIONS}

The end of the Cold War has led the United Nations Security Council to intensify its use of economic sanctions. The generally accepted purpose and emphasis of such sanctions lies in modifying behavior, not in punishment. ${ }^{1}$ However, their increased use has also brought to light various shortcomings and problems. Apart from the decades-old debate on their effectiveness, which depends, of course, on such factors as the policy goals set for sanctions, the criteria for measuring their success, the economic development of the target state, and the level of its economic relations with others, ${ }^{2}$ a few facts are relatively certain.

Thus, economic sanctions "theory" maintains that economic pressure on civilians will translate into pressure on the government for change, but the targeted leaders, sometimes expressly intended to be ousted by their outraged peoples, have managed to continue pursuing their policies and to stay in power. Part of the reason for this effect derives from the leaders' ability to "retranslate" the message of sanctions into punishment and retribution against the country, which enhances popular support for the regime in "rally round the flag" fashion. ${ }^{3}$

Further, sanctions have unintentionally contributed to the emergence of black markets, creating huge profit-making opportunities for ruling elites and their collaborators. ${ }^{4}$ Worst of all, economic sanctions tend to hit the wrong targets; instead of the regime, the population at large and in particular the weakest in society become the true victims. ${ }^{5} \mathrm{~A}$ par-

\footnotetext{
- Executive Vice President and Executive Director, The American Society of International Law.

${ }^{1}$ SUPPLEMENT TO AN AGENDA FOR PEACE, UN Doc. A/50/60-S/1995/1, para. 66 (1995).

${ }^{2}$ There is a vast literature on these issues. See, e.g., MARGARET P. DOXEY, INTERNATIONAL SANCTIONS IN CONTEMPORARY PERSPECTIVE (2d ed. 1996); DANIELW.DREZNER, THESANCTIONSPARADOX:ECONOMICSTATECRAFT AND INTERNATIONAL RELATIONS (1999); GARY CLYDE HUFBAUER, JEFFREY J. SCHOTT, \& KIMBERLY ANN ELLIOTT, ECONOMICSANCTIONS RECONSIDERED (2d ed. 1990).

${ }^{3}$ SUPPLEMENT TO AN AGENDA FOR PEACE, supra note 1, para. 70.

"See Milliennium Report of THe Secretary-General of The United Nations, "We the Peoples": The Role OF THE UNITED NATIONS IN THE 21sT CENTURY at 50, UN Sales No. 00.I.16 (2000).

${ }^{5}$ Nico Schrijver, The Use of Economic Sanctions by the UN Security Council: An International Law Perspective, in INTERNATIONAL ECONOMIC LAW AND ARMED CONFLICT 123, 156 (Hanty H. G. Post ed., 1994).
} 